\title{
Kemampuan Berpikir Kritis Matematis serta Habits Of Mind Menggunakan Model Inquiry Learning dan Model Creative Problem Solving
}

\author{
Samsul Nurdiansyah ${ }^{1}$, Rostina Sundayana ${ }^{2 *}$, dan Teni Sritresna ${ }^{3}$ \\ Program Studi Pendidikan Matematika, Fakultas Ilmu Terapan dan Sains, IPI Garut \\ Jalan Pahlawan No 32, Sukagalih, Tarogong, Garut, Jawa Barat, Indonesia \\ ${ }^{1}$ samsulnurdiansyah@gmail.com; ${ }^{2 *}$ sundayanaros@gmail.com; ${ }^{3}$ sritresnateni@gmail.com
}

Artikel diterima: 22-09-2020, direvisi: 27-01-2021, diterbitkan: 31-01-2021

\begin{abstract}
Abstrak
Kemampuan berpikir kritis matematis dan Habits of Mind merupakan salah satu kemampuan dasar yang harus dimiliki oleh siswa. Fakta menunjukkan bahwa kemampuan berpikir kritis matematis dan Habits of Mind siswa masih rendah. Diperlukan upaya untuk meningkatkan kemampuan berpikir kritis matematis dan Habits of Mind siswa salah satunya menggunakan model Inquiry Learning dan model pembelajaran Creative Problem Solving. Tujuan dari penelitian ini adalah menganalisis perbedaan kemampuan berpikir kritis matematis dan Habits of Mind antara siswa yang mendapatkan model Inquiry Learning dengan Creative Problem Solving. Metode penelitian yang digunakan adalah kuasi eksperimen dengan populasi seluruh siswa kelas X SMA Negeri 11 Garut. Sampel pada penelitian ini sebanyak dua kelas yaitu kelas X-MIPA 5 sebanyak 35 siswa sebagai kelas eksperimen I yang mendapat model Inquiry Learning dan kelas X-MIPA 6 sebanyak 35 siswa sebagai kelas eksperimen II yang mendapat model pembelajaran Creative Problem Solving. Instrumen penelitian yang digunakan berupa tes uraian dan angket skala Likert. Berdasarkan hasil analisis secara statistik diperoleh kesimpulan bahwa terdapat perbedaan kemampuan berpikir kritis matematis dan Habits of Mind antara siswa yang mendapatkan model Inquiry Learning dengan Creative Problem Solving. Untuk meningkatkan kemampuan berpikir kritis matematis dan Habits of Mind, model Inquiry Learning cocok digunakan.
\end{abstract}

Kata Kunci: Berpikir Kritis Matematis, Creative Problem Solving, Habits of Mind, Inquiry Learning

\section{Mathematic Critical Thinking Ability And Habits Of Mind Using Inquiry Learning Model And Creative Problem Solving Model}

\begin{abstract}
Mathematical Critical Thinking Skills and Habits of Mind are some of the basic abilities that students must have. The fact shows that the Mathematical Critical Thinking Skills and Habits of Mind are still low. Efforts are needed to improve the Mathematical Critical Thinking Skills and Habits of Mind, one of them using the Inquiry Learning and the Creative Problem Solving learning. The purpose of this research was to analyze the differences in Mathematical Critical Thinking Skills and Habits of Mind between students who get the Inquiry Learning model with Creative Problem Solving. The research method used a quasi-experimental with a population of all class $X$ of SMAN 11 Garut. Sample consisted of two classes, class $X$ Science 5 by 35 students as the first experimental class, which got Inquiry Learning model, and class $X$ Science 6 by 35 students as the second experimental class which got Creative Problem-Solving learning model. The research instrument used a description test and a Likert scale questionnaire. Based on the results of statistical analysis, it is found that there are differences in Mathematical Critical Thinking Skills and Habits of Mind between students who get the Inquiry Learning model with Creative Problem Solving. To improve mathematical critical thinking skills and Habits of Mind, the Inquiry Learning model is suitable. Keywords: Mathematical Critical Thinking, Creative Problem Solving, Habits of Mind, Inquiry Learning.
\end{abstract}




\section{Pendahuluan}

Materi matematika dan keterampilan berpikir kritis merupakan dua hal yang tidak dapat dipisahkan, karena materi matematika dipahami melalui berpikir kritis, dan berpikir kritis dilatih melalui belajar matematika (Novitasari, 2015). Oleh karena itu, kemampuan berpikir kritis merupakan salah satu faktor yang perlu mendapat perhatian dan harus dikembangkan dalam pelaksanaan proses pembelajaran matematika.

Umar (2013) mengemukakan bahwa, kemampuan yang harus dikembangkan dalam pembelajaran matematika tidak hanya mencakup aspek kognitif tetapi juga aspek afektif. Miliyawati (2014) melalui penelitiannya menyimpulkan bahwa terdapat hubungan yang positif antara sikap dengan prestasi matematika. Selain itu, hasil penelitian Dwirahayu dan Firdausi (2016) menyimpulkan bahwa sikap dan karakter siswa berpengaruh pada kemampuan menangkap materi pembelajaran yang diberikan. Dari beberapa pendapat tersebut mengindikasikan bahwa dalam pembelajaran matematika, aspek afektif pun penting untuk diperhatikan Aspek afektif siswa ini dapat menunjang kemampuan berpikir kritis matematis siswa juga membentuk karakter siswa.

Dalam proses pembelajaran matematika, terdapat aspek pembentukan karakter. Hal inilah yang disebut dengan Habits of Mind. Dwirahayu, Kustiawati, \& Bidari (2018) menyebutkan bahwa Habits of mind merupakan kecenderungan perilaku cerdas yang dimiliki seseorang untuk menyelesaikan permasalahan yang dia hadapi, namun dengan segera ia memiliki ide cara solusinya. Kebiasaan berpikir tersebut akan membantu mengatasi masalah yang dihadapinya dengan tindakan yang produktif. Selain itu, menurut Nurmala, Rohaeti, dan Sariningsih (2019), Habits of Mind yang dimiliki siswa dapat mempengaruhi kemampuan pemecahan masalah siswa. Oleh karena itu, dalam pembelajaran matematika selain mengembangkan kemampuan berpikir kritis siswa juga penting bagi pendidik untuk dapat mengembangkan Habits of Mind (kebiasaan berpikir).

Berdasarkan hasil penelitian Hidayanti, As'ari, \& Daniel (2016) menunjukkan pula bahwa kemampuan berpikir kritis siswa masih tergolong rendah pada indikator mengidentifikasi, evaluasi, dan inferensi. Hasil penelitian Razak (2017) Kemampuan berpikir kritis siswa di memiliki rata-rata sebesar 41,72 di mana pada nilai tersebut berada pada kategori sangat kurang. Hal ini menunjukkan bahwa kemampuan berpikir kritis matematis siswa menjadi salah satu kebutuhan yang perlu dikembangkan oleh guru dalam pembelajaran matematika.

Selain itu, aspek afektif khususnya Habits of Mind siswa masih belum diperhatikan dan nampak bahwa guru dalam hal ini sebagai pendidik serta satuan pendidikan masih terkonsentrasikan terhadap pengembangan aspek kognitif saja. Dwirahayu, dkk.

(2018) 
mengemukakan bahwa, pembelajaran di sekolah masih banyak menekankan pada aspek kognitif dan kurang memberikan perhatian pada aspek afektif mengenai pembentukan sikap atau karakter siswa.

Merujuk pada pentingnya kemampuan berpikir kritis matematis dan Habits of Mind, keduanya mesti dimunculkan dan diberi perhatian dalam proses pembelajaran matematika. Pembelajaran yang inovatif adalah pembelajaran yang terbukti dapat mengembangkan kemampuan berpikir dan disposisi matematis (Sumarmo, 2010). Selain itu, Sundayana (2019) mengatakan bahwa, dalam pembelajaran matematika aspek karakter siswa dan media pembelajaran perlu mendapat perhatian yang khusus, disamping memperhatikan aspek tujuan pengajaran yang ingin dicapai. Dengan demikian dalam pembelajaran matematika, kemampuan berpikir kritis matematis serta Habits of Mind siswa perlu dikembangkan dengan cara mempraktikan desain dan model pembelajaran yang inovatif dengan memperhatikan pula karakteristik siswa.

Azizah dan Sundayana (2016) mengemukakan bahwa guru haruslah berkesinambungan mengembangkan dan memilih model-model pembelajaran yang dianggap mampu dapat meningkatkan motivasi belajar. Salah satu model pembelajaran yang diduga dapat meningkatkan kemampuan berpikir kritis dan Habits of Mind siswa adalah model Inquiry Learning dan model pembelajaran Creative Problem Solving (CPS). Hal ini didukung oleh penelitian yang dilakukan Setiawan dan Royani (2013) di Banjarmasin dengan menggunakan model Inquiry Learning berada pada kualifikasi aktif dengan rata-rata presentase kemampuan berpikir kritis siswa 79,49 sedangkan untuk ketuntasan secara klasikal jumlah siswa yang memenuhi kualifikasi tuntas dengan presentase 87,10\%. Prameswari, Apriana, dan Wahyuni (2018) menunjukan bahwa adanya pengaruh yang signifikan antara model Inquiry Learning terhadap kemampuan berpikir kritis matematis siswa. Model Inquiry Learning dapat memotivasi siswa untuk lebih aktif, juga merupakan model pembelajaran yang melaksanakan adanya ahapan diskusi kelompok sehingga siswa dapat menyimak, mengemukakan pendapat, dan bekerja sama dalam kelompoknya sehingga pembelajaran tidak lagi menjenuhkan. Model Inquiry Learning merupakan model pembelajaran yang menekankan pada proses berpikir kritis dan analisis yang dalam prosesnya terdapat pelaksanaan diskusi kelompok untuk mencari dan menemukan jawaban dari suatu masalah yang diberikan.

Novitasari (2015) menyimpulkan bahwa peningkatan kemampuan berpikir kritis siswa yang mendapat pembelajaran dengan pendekatan Creative Problem Solving (CPS) lebih baik daripada siswa yang mendapat pembelajaran konvensional. Selain itu, Mahmudah dkk. (2015). Model pembelajaran CPS memberikan pengaruh lebih efektif dibandingkan dengan model 
pembelajaran konvensional yang dapat dilihat dari nilai rata-rata posttest kelas yang menggunakan model CPS cenderung lebih tinggi dibandingkan dengan rata-rata posttest kelas yang menggunakan model konvensional. Adapun model pembelajaran CPS adalah suatu model pembelajaran yang memusatkan pada pengajaran dan keterampilan pemecahan masalah, yang diikuti dengan penguatan keterampilan, memecahkan masalah dapat membantu siswa berpikir kritis (Pepkin, 2000).

Sanjaya, (2008) menyebutkan terdapat enam langkah pembelajaran model Inquiry Learning menurut. yaitu: 1) Orientasi; 2) merumuskan masalah; 3) merumuskan hipotesis; 4) mengumpulkan data; 5) menguji hipotesis; dan 6) merumuskan kesimpulan. Sedangkan pembelajaran model Inquiry Learning menurut Setiawan dan Royani (2013) langkah-langkahnya sebagai berikut: 1) Menyajikan pertanyaan atau masalah; 2) membuat Hipotesis; 3) merancang percobaan; 4) Melakukan percobaan untuk memperoleh informasi; 5) Mengumpulkan dan menganalisis data; dan 6) membuat kesimpulan.

Mitchell dan Kowalik menjelaskan bahwa langkah-langkah model pembelajaran CPS adalah 1) Messfinding, yaitu melakukan mengidentifikasi suatu situasi; 2) Fact-finding, yaitu melakukan mencatat semua fakta yang diketahui dan berhubungan dengan situasi; 3) Problem-finding, yaitu menemukan dan memilih masalah yang paling penting untuk dipecahkan; 4) Idea-finding, yaitu menemukan sejumlah cara yang mungkin dapat digunakan untuk memecahkan masalah; 5) Solution-finding, yaitu penemuan solusi, ide dan gagasan yang telah diperoleh; 6) Acceptance-finding, yaitu penerimaan atas solusi yang diambil, menyusun rencana tindakan, dan mengimplementasikan solusi tersebut. Sedangkan Lestari dan Sofyan (2013) mengemukakan bahwa model pembelajaran CPS mempunyai langkahlangkah, yaitu: 1) Klarifikasi masalah; 2) pengungkapan pendapat; 3) evaluasi dan pemilihan; 4) Implementasi.

Berdasarkan uraian tersebut, dalam penelitian ini dibahas berkenaan dengan: a) perbedaan kemampuan berpikir kritis matematis antara siswa yang mendapatkan model Inquiry Learning dengan Creative Problem Solving, b) kualitas peningkatan kemampuan berpikir kritis matematis yang mendapatkan model Inquiry Learning dan Creative Problem Solving, c) perbedaan Habits of Mind antara siswa yang mendapatkan model Inquiry Learning dengan Creative Problem Solving, d) kualitas peningkatan Habits of Mind siswa yang mendapatkan model Inquiry Learning dan Creative Problem Solving, e) hubungan antara peningkatan Habits of Mind dan peningkatan kemampuan berpikir kritis matematis siswa.

\section{Metode}

Metode penelitian yang digunakan adalah metode kuasi eksperimen. Populasi dalam penelitian ini adalah seluruh siswa di 
SMAN 11 Garut tahun ajaran 2019-2020. Sedangkan penentuan sampel dalam penelitian ini menggunakan teknik Sampling Purposive. Adapun sampel yang diambil yaitu kelas X MIPA 5 sebagai kelas eksperimen kesatu yang mendapatkan model Inquiry Learning dan kelas X MIPA 6 sebagai kelas eksperimen kedua yang mendapatkan model pembelajaran Creative Problem Solving, masing-masing kelas tersebut mempunyai jumlah siswa yang sama banyak yaitu 35 orang. Pengambilan kedua kelas tersebut berdasarkan pertimbangan guru bersangkutan bahwa kedua kelas memiliki kemampuan yang setara. Desain penelitian yang digunakan sebagai berikut:

$\begin{array}{ccc}0 & x_{1} & 0 \\ 0 & x_{2} & 0\end{array}$

(Russeffendi, 2005)

Penelitian ini melibatkan dua jenis instrumen yaitu tes dan nontes. Untuk mengukur kemampuan berpikir kritis matematis peneliti menggunakan instrument berbentuk soal-soal kemampuan berpikir kritis matematis materi tentang sistem pertidaksamaan linier. Sedangkan untuk mengukur Habits of Mind siswa peneliti menggunakan angket dengan skala Likert. Kedua kelompok tersebut diberikan soal-soal dan angket yang sama pada awal dan akhir pembelajaran.

Indikator kemampuan berpikir kritis matematis yang dikaji yaitu: memberikan penjelasan sederhana; memberikan penjelasan lanjut;

1)

2)

3) menentukan strategi, taktik, dan penyelesaian suatu permasalahan; dan 4) menyimpulkan dan mengevaluasi, mencari alternatif-alternatif lain penyelesaian suatu permasalahan dengan tepat. Sedangkan untuk Habits of Mind, peneliti membatasi indikator yang diteliti yaitu : (1) Bertahan atau pantang menyerah; (2) mengatur kata hati; (3) mendengarkan pendapat orang lain dengan rasa empati; (4) berpikir luwes; (5) berpikir metakognitif; (6) berusaha bekerja teliti dan tepat; (7) bertanya dan mengajukan masalah secara efektif; (8) memanfaatkan pengalaman lama untuk membentuk pengetahuan baru; (9) berpikir dan berkomunikasi secara jelas dan tepat; (10) memanfaatkan indera dalam mengumpulkan dan mengolah data; (11) mencipta, berkhayal, dan berinovasi; (12) bersemangat dalam merespons; (13) berani bertanggung jawab dan menghadapi resiko; (14) humoris; (15) berpikir saling bergantungan; (16) belajar berkelanjutan. Costa \& Kallick, 2008)

\section{Hasil dan Pembahasan}

Secara deskriptif statistika, mengenai kemampuan berpikir kritis matematis siswa pada pretest, posttest, dan gain disajikan pada Tabel 1 berikut:

Tabel 1.

Data Hasil Penelitian Kemampuan Berpikir Kritis

\begin{tabular}{lllllll}
\multicolumn{1}{l}{ Siswa } \\
Kelompok & $\mathrm{n}$ & $\boldsymbol{x}_{\max }$ & $\boldsymbol{x}_{\min }$ & $\overline{\boldsymbol{x}}$ & $\mathrm{s}$
\end{tabular}

$\begin{array}{llllllll} & & \boldsymbol{x}_{\boldsymbol{m a x}} & \boldsymbol{x}_{\boldsymbol{m i n}} & \overline{\boldsymbol{x}} & \text { s } \\ \text { Inquiry } & \text { Pretest } & 35 & 6 & 0 & 1,97 & 1,76\end{array}$

\begin{tabular}{|c|c|c|c|c|c|c|}
\hline \multirow{3}{*}{$\begin{array}{l}\text { Inquiry } \\
\text { Learning }\end{array}$} & Pretest & \multirow[t]{3}{*}{35} & 6 & 0 & 1,97 & 1,76 \\
\hline & Posttest & & 14 & 2 & 7,69 & 4,04 \\
\hline & Gain & & 0,83 & 0,07 & 0,42 & 0,25 \\
\hline CPS & Pretest & 35 & 6 & 0 & 1,35 & 1,80 \\
\hline
\end{tabular}




\begin{tabular}{|c|c|c|c|c|}
\hline Posttest & 14 & 2 & 5,44 & 3,8 \\
\hline Gain & 0,80 & 0,07 & 0,29 & 0,2 \\
\hline
\end{tabular}

Dari Tabel 1 diperoleh bahwa nilai ratarata Pretest antara kelompok Inquiry Learning dan kelompok CPS hanya berbeda sebesar 0,62. Namun setelah diberi perlakuan, pencapaian posttest kedua kelas memiliki rata-rata yang berbeda sebesar 2,25 . Begitu pula dengan peningkatan (gain) memiliki rata-rata yang berbeda sebesar 0,04. Namun demikian, kita perlu menguji secara statistik, mengenai signifikansi perbedaan yang muncul.

Sebelum diberikan perlakuan model pembelajaran, kedua kelas diberikan pretest terlebih dahulu untuk mengetahui kemampuan awalnya, dengan rata-rata pada masing-masing kelas yaitu 1,97 dan 1,35. Data tersebut kemudian di uji normalitasnya menggunakan uji Lilliefors dengan taraf signifikansi 5\% diperoleh bahwa kedua kelompok data berdistribusi tidak normal, sehingga langkah pengujian selanjutnya menggunakan uji MannWhitney. Dari hasil perhitungan uji MannWhitney didapatkan nilai $z_{\text {hitung }}=-1,787$ berada pada daerah penerimaan Ho. Dengan kata lain, terdapat kesamaan kemampuan awal berpikir kritis matematis antara siswa yang mendapatkan model Inquiry Learning dengan Creative Problem Solving.

Berdasarkan hasil Posttest kemampuan berpikir kritis matematis siswa setelah diberikan perlakuan yang berbeda yakni dengan model Inquiry Learning dan CPS berturut-turut mendapatkan rata-rata skor sebesar 7,69 dan 5,44. Dengan menggunakan uji Mann-Whitney diperoleh kesimpulan, terdapat perbedaan kemampuan berpikir kritis matematis antara siswa yang mendapatkan model Inquiry Learning dengan Creative Problem Solving.

Sedangkan untuk rincian kualitas peningkatan kemampuan berpikir kritis matematis pada kelas Inquiry Learning dan CPS ditunjukkan pada Tabel 2 berikut:

Tabel 2.

Data Persentase Peningkatan Kemampuan Berpikir Kritis Matematis

\begin{tabular}{|ccccc|}
\hline \multirow{2}{*}{$\begin{array}{c}\text { Interpretasi } \\
\text { Gain }\end{array}$} & \multicolumn{2}{c}{$\begin{array}{c}\text { Inquiry } \\
\text { Learning }\end{array}$} & \multicolumn{2}{l}{ CPS } \\
\cline { 2 - 5 } Ternormalisasi & $\mathrm{f}_{\mathrm{i}}$ & $\mathbf{( \% )}$ & $\mathrm{f}_{\mathrm{i}}$ & $\mathbf{( \% )}$ \\
\hline Rendah & 15 & 42,86 & 24 & 68,57 \\
\hline Sedang & 13 & 37,14 & 8 & 22,86 \\
\hline Tinggi & 7 & 20 & 3 & 8,57 \\
\hline
\end{tabular}

Berdasarkan indikator kemampuan berpikir kritis matematis (memberikan penjelasan sederhana; memberikan penjelasan lanjut; menentukan strategi, taktik, dan penyelesaian suatu permasalahan; serta menyimpulkan dan mengevaluasi, mencari alternatif-alternatif lain, disajikan pada Tabel 3 berikut:

Tabel 3.

Interpretasi Peningkatan Indikator Kemampuan Berpikir Kritis Matematis

\begin{tabular}{|ccccc|}
\hline \multirow{2}{*}{ Kelompok } & \multicolumn{4}{c}{ Nomor Indikator } \\
\cline { 2 - 5 } & $\mathbf{1}$ & $\mathbf{2}$ & $\mathbf{3}$ & $\mathbf{4}$ \\
\hline $\begin{array}{c}\text { Inquiry } \\
\text { Learning }\end{array}$ & Sedang & Sedang & Sedang & Sedang \\
\hline CPS & Sedang & Rendah & Rendah & Rendah
\end{tabular}

Berdasarkan data pada Tabel 3 di atas, terlihat bahwa untuk kelompok yang menggunakan model Inquiry Learning peningkatan untuk ke-4 indikator 
mempunyai interpretasi sedang. Sedangkan untuk kelas yang mendapatkan model Creative Problem Solving untuk indikator ke-1 mempunyai interpretasi sedang sedangkan untuk indikator ke-2, ke3, dan ke-4 mempunyai indikator rendah.

Selain menganalisis kualitas peningkatan, peneliti pun melakukan analisis ketuntasan belajar siswa dengan tujuan untuk mengetahui banyaknya siswa yang tuntas dan tidak tuntas dalam mencapai nilai KKM setelah mendapatkan pembelajaran dengan model Inquiry Learning dan Creative Problem Solving. Dari hasil perhitungan yang diperoleh data pada Tabel 4 berikut:

Tabel 4.

Rekapitulasi Ketuntasan Belajar

\begin{tabular}{ccccc}
\hline Pencapaian & \multicolumn{2}{c}{$\begin{array}{c}\text { Inquiry } \\
\text { Learning }\end{array}$} & \multicolumn{2}{l}{ CPS } \\
\cline { 2 - 5 } & $\mathrm{f}_{\mathrm{i}}$ & $(\%)$ & $\mathrm{f}_{\mathrm{i}}$ & $\%$ \\
\hline Tidak Tuntas & 21 & 60 & 29 & 82,86 \\
\hline Tuntas & 14 & 40 & 6 & 17,14
\end{tabular}

Berdasarkan indikator kemampuan berpikir kritis matematis, diperoleh data seperti pada Tabel 5 berikut:

Tabel 5.

Persentase Pencapaian Tiap Indikator Kemampuan Berpikir Kritis Matematis

\begin{tabular}{|c|c|c|c|c|}
\hline \multirow[t]{2}{*}{ Model } & \multicolumn{4}{|c|}{$\begin{array}{c}\text { Persentase Pencapaian } \\
\text { Indikator } \\
(\%)\end{array}$} \\
\hline & 1 & 2 & 3 & 4 \\
\hline $\begin{array}{l}\text { Inquiry } \\
\text { Learning }\end{array}$ & 72,86 & 41,43 & 37,14 & 40,71 \\
\hline CPS & 60,71 & 35,00 & 22,14 & 16,43 \\
\hline
\end{tabular}

Adapun hasil skala Habits of Mind siswa pada pembelajaran matematika diperoleh dengan memberikan angket. Butir angket tersebut berjumlah 23 pernyataan yang terdiri dari pernyataan positif dan pernyataan negatif. Data Habits of Mind siswa dianalisis dengan pemberian skor menggunakan penskoran skala likert. Sebelum diuji statistik, data tersebut ditransformasi terlebih dahulu ke dalam data interval dengan menggunakan MSI. Adapun deskripsi data hasil skala Habits of Mind siswa ada pada Tabel 6 berikut:

Tabel 6.

Data Hasil Penelitian Habits of Mind Siswa

\begin{tabular}{|c|c|c|c|c|c|}
\hline \multicolumn{2}{|c|}{ Kelompok } & $x_{\max }$ & $x_{\min }$ & $\overline{\bar{x}}$ & $\mathrm{~S}$ \\
\hline \multirow{3}{*}{$\begin{array}{l}\text { Inquiry } \\
\text { Learning }\end{array}$} & Awal & 67,72 & 54,80 & 58,76 & 2,848 \\
\hline & Akhir & 99,16 & 69,28 & 79,65 & 9,357 \\
\hline & Gain & 0,82 & 0,24 & 0,43 & 0,18 \\
\hline \multirow[t]{3}{*}{ CPS } & Awal & 82,16 & 47,07 & 59,13 & 6,056 \\
\hline & Akhir & $\begin{array}{c}100,3 \\
8\end{array}$ & 60,31 & 72,06 & 9,560 \\
\hline & Gain & 0,74 & 0,05 & 0,27 & 0,17 \\
\hline
\end{tabular}

Dari Tabel 6 diperoleh bahwa nilai ratarata skala Habits of Mind pada awal pembelajaran hanya berbeda sebesar 0,37. Namun setelah diberi perlakuan, perbedaan pencapaian skala Habits of Mind kedua kelompok menjadi 7,59. Begitu pula dengan peningkatan (gain) memiliki perbedaan rata-rata sebesar 0,16. Namun demikian, kita perlu menguji secara statistik, mengenai signifikansi perbedaan yang muncul.

Sebelum diberikan perlakuan model pembelajaran, kedua kelas diberikan angket terlebih dahulu untuk mengetahui Habits of Mind awalnya, dengan rata-rata pada masing-masing kelas yaitu 58,76 dan 59,13 . Dengan menggunakan uji MannWhitney. Diperoleh kesimpulan terdapat kesamaan Habits of Mind sebelum dilakukan pembelajaran antara siswa yang 
mendapatkan model Inquiry Learning dengan Creative Problem Solving pada awal pembelajaran. Namun, setelah siswa diberikan perlakuan yang berbeda yakni dengan model Inquiry Learning dan CPS berturut-turut mendapatkan rata-rata skor sebesar 79,65 dan 72,06. Berdasarkan hasil pengujian, diperoleh terdapat perbedaan Habits of Mind setelah dilakukan pembelajaran antara siswa yang mendapatkan model Inquiry Learning dengan Creative Problem Solving.

Berikut interpretasi habits of mind siswa secara umum, per-indikator, dan per-siswa.

Tabel 7.

Interpretasi Habits of Mind Siswa Secara Umum

\begin{tabular}{ccccc|}
\hline Kelas & Data & $\begin{array}{c}\text { Skor } \\
\text { Total }\end{array}$ & (\%) & Interpretasi \\
\hline Inquiry & Pretest & 2056,48 & 54,38 & Cukup \\
\cline { 2 - 5 } Learning & Posttest & 2787,64 & 73,72 & Baik \\
\hline \multirow{2}{*}{ CPS } & Pretest & 2069,58 & 54,73 & Cukup \\
\cline { 2 - 5 } & Posttest & 2522,11 & 66,70 & Cukup \\
\hline
\end{tabular}

Lebih rinci, dilihat berdasarkan indikator dapat dilihat pada Tabel berikut:

Tabel 8.

Interpretasi Habits of Mind Siswa Tiap Indikator

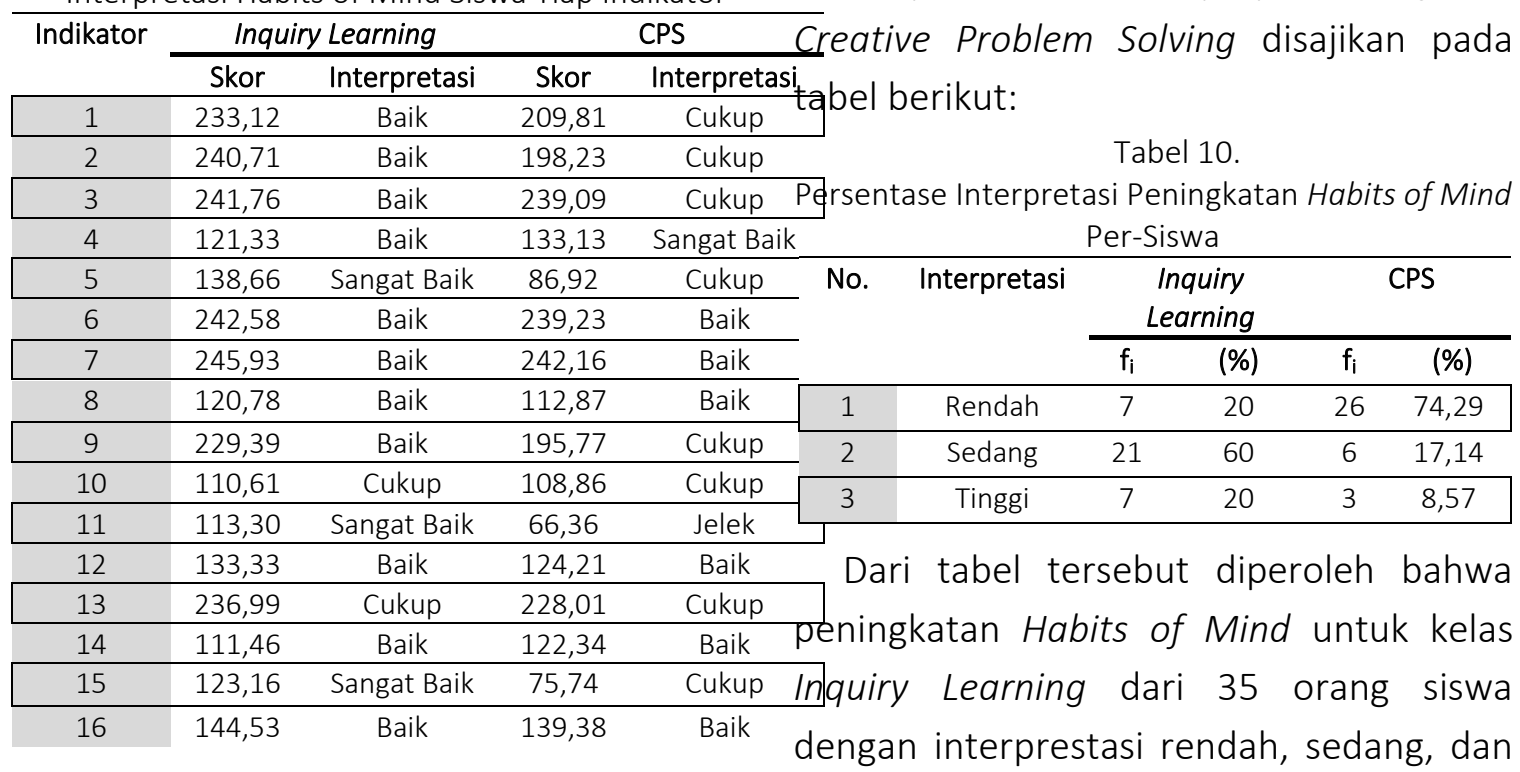

Sama halnya dengan interpretasi Habits of Mind siswa secara umum, Habits of Mind tiap siswa juga dilakukan perhitungan uji statistik yang sesuai dengan langkahlangkahnya dan hasil yang diperoleh disajikan dalam tabel berikut:

Tabel 9.

Persentase Interpretasi Habits of Mind Per-Siswa

\begin{tabular}{ccccc|}
\hline Interpretasi & \multicolumn{2}{c}{$\begin{array}{c}\text { Inquiry } \\
\text { Learning }\end{array}$} & \multicolumn{2}{c}{ CPS } \\
\cline { 2 - 5 } & $f_{\mathrm{i}}$ & $\mathbf{( \% )}$ & $f_{\mathrm{i}}$ & $(\%)$ \\
\hline Cukup & 10 & 28,57 & 29 & 82,86 \\
\hline Baik & 18 & 51,43 & 3 & 8,57 \\
\hline Sangat Baik & 7 & 20,00 & 3 & 8,57 \\
\hline
\end{tabular}

Dari tabel tersebut diperoleh bahwa untuk kelas Inquiry Learning dari 35 orang siswa dengan interprestasi cukup, baik, dan sangat baik secara berturut-turut mencapai persentase sebesar 28,57 \%, 51,43 \%, dan 20\%. Sedangkan untuk kelas CPS masingmasing berturut-turut sebesar $82,86 \%$, $8,57 \%$, dan $8,57 \%$.

Adapun rincian persentase kualitas peningkatan kelompok siswa yang mendapatkan model Inquiry Learning dan Creative Problem Solving disajikan pada 
tinggi secara berturut-turut mencapai persentase sebesar 20\%,60\%, dan 20\%. Sedangkan untuk kelas CPS masing-masing berturut-turut sebesar 74,29\%, 17,14\%, dan $8,57 \%$.

Adapun pencapaian peningkatan tiap indikator, dapat dilihat dari tabel berikut:

Tabel 11.

Persentase Interpretasi Peningkatan Habits of Mind

\begin{tabular}{|lll|}
\hline \multicolumn{4}{c}{ Per-Indikator } \\
\hline & Kelompok \\
\cline { 2 - 3 } & Inquiry Learning & CPS \\
\hline 2 & Sedang & Rendah \\
\hline 3 & Sedang & Rendah \\
\hline 4 & Sedang & Rendah \\
\hline 5 & Sedang & Sedang \\
\hline 6 & Tinggi & Rendah \\
\hline 7 & Sedang & Sedang \\
\hline 8 & Sedang & Sedang \\
\hline 9 & Sedang & Sedang \\
\hline 10 & Sedang & Rendah \\
\hline 11 & Sedang & Sedang \\
\hline 12 & Tinggi & Rendah \\
\hline 13 & Sedang & Rendah \\
\hline 14 & Sedang & Rendah \\
\hline 15 & Sedang & Sedang \\
\hline 16 & Tinggi & Rendah \\
\hline
\end{tabular}

Peningkatan Habits of Mind siswa, baik di kelas yang mendapatkan model Inquiry Learning maupun di kelas yang mendapatkan model pembelajaran Creative Problem Solving secara umum mempunyai hubungan yang signifikan terhadap peningkatan kemampuan berpikir kritis matematis siswa. Hubungan tersebut dapat terlihat dari interpretasi peningkatan Habits of Mind dan kemampuan berpikir kritis matematis pada kedua kelas yang mempunyai interpretasi sama baik pada Habits of Mind maupun kemampuan berpikir kritis matematis, yaitu sedang pada kelas Inquiry Learning dan rendah pada kelas Creative Problem Solving.

Berdasarkan hal tersebut, untuk memastikan signifikansi hubungan peningkatan Habits of Mind siswa dengan kemampuan berpikir kritis matematis siswa perlu dilakukan pengujian statistik. Berdasarkan data peningkatan Habits of Mind dan Kemampuan berpikir kritis matematis salah satu sebaran datanya berdistribusi tidak normal. Sehingga untuk menentukan koefisien korelasi $\left(r_{s}\right)$ ditentukan dengan rumus Rank Spearman. Dari hasil perhitungan dengan menggunakan rumus Rank Spearman diperoleh nilai koefisien korelasi sebesar 0,7809, maka setelah dilakukan pengujian diperoleh kesimpulan bahwa terdapat hubungan yang signifikan antara Habits of Mind dengan kemampuan berpikir kritis matematis siswa secara umum.

Pengaruh peningkatan Habits of Mind siswa tersebut terhadap peningkatan kemampuan kognitif siswa yang dalam hal ini adalah kemampuan berpikir kritis matematis sebesar 60,98\%. Hal ini sejalan dengan hasil penelitian Dwirahayu dkk. (2018) yaitu Habits of Mind berpengaruh positif terhadap kemampuan generalisasi matematis siswa dengan pengaruh sebesar 42,5\%. Selain itu, Nurmala dkk. (2019) mengungkapkan bahwa berdasarkan hasil penelitian yang telah dilakukannya di salah satu sekolah di Cimahi diperoleh bahwa Habits of Mind (Kebiasaan berpikir) dan kemampuan pemecahan masalah siswa ada yang tinggi, sedang dan rendah, hal ini 
menunjukkan bahwa Habits of Mind yang dimiliki siswa dapat mempengaruhi terhadap peningkatan kemampuan pemecahan masalah siswa.

Ada beberapa hal yang menyebabkan perbedaan kemampuan berpikir kritis matematis dan Habits of Mind antara siswa yang mendapatkan model Inquiry Learning dengan Creative Problem Solving yaitu faktor internal dan eksternal. Faktor internal adalah faktor yang berasal dari siswa meliputi faktor fisiologi dan faktor psikologi, sedangkan faktor eksternal adalah faktor yang berasal dari luar diri siswa meliputi faktor lingkungan (keluarga, sekolah, masyarakat, waktu), dan faktor instrumen.

Salah satu faktor eksternal yang sering terjadi dalam permasalahan ini adalah faktor peletakan waktu atau jadwal pembelajaran. Menurut peneliti sering kali jam pelajaran yang diterapkan oleh sekolah tampak belum efektif, khususnya pada mata pelajaran matematika. Peletakan jam pelajaran matematika tidaklah sama untuk tiap-tiap kelas. Terdapat kelas yang mendapatkan pelajaran matematika di jam awal dan juga pelajaran di jam akhir. Pada jam akhir pelajaran kondisi siswa sudah lelah, baik secara jasmani maupun rohani, semangat belajar rendah, serta konsentrasi tidak sepenuhnya tertuju pada pelajaran. (Sumantri, 2014).

Selain dari itu faktor yang mempengaruhi hasil penelitian ini adalah faktor sintaks pembelajaran, sikap siswa selama pembelajaran, kemampuan awal matematika siswa, serta kesulitan materi yang dipelajari. Materi pembelajaran yang diberikan sangat mempengaruhi, karena tidak semua bahan ajar dapat diberikan hanya dengan model Inquiry Learning ataupun CPS.

\section{Penutup}

Berdasarkan hasil penelitian, rekomendasi dari peneliti adalah kedua model tersebut dapat digunakan untuk meningkatkan kemampuan berpikir kritis matematis dan Habits of Mind siswa dengan memperhatikan beberapa hal, yaitu: materi yang akan diberikan; Indikator kemampuan yang akan diteliti maupun dicapai oleh siswa; aktivitas siswa; Jadwal pelajaran matematika; LKS yang digunakan, dan lainnya.

\section{Daftar Pustaka}

Azizah, G. N., \& Sundayana, R. (2016). Kemampuan Pemecahan Masalah Matematis dan Sikap Siswa terhadap Model Pembelajaran Kooperatif Tipe Air dan Probing-Prompting. Mosharafa: Jurnal Pendidikan Matematika, 5(3). 305-314.

Costa, AL., \& Kallick, B. (2008). Leading and Learning with Habits of Mind 16 Essential Characteristic for Success. (United States of America: Association for Supervision and Curriculum Development).

Dwirahayu, G. Kustiawati, D \& Bidari, I. (2018). Pengaruh Habits of Mind 
terhadap Kemampuan Generalisasi Matematis. [Online]. Jurnal Pendidikan Matematika (JPPM), 11(2), 91-104.

Dwirahayu, G., \& Firdausi (2016) Pengaruh Gaya Berpikir terhadap Kemampuan Koneksi Matematis Mahasiswa (Studi Kasus di Jurusan Pendidikan Matematika FITK). [Online]. Jurnal Penelitian dan Pembelajaran Matematika (JPPM), 9(2).

Hidayanti, D., As'ari, A.R., \& Daniel, T. (2016). Analisis Kemampuan Berpikir Kritis Siswa SMP Kelas IX pada Materi Kesebangunan. [Online]. Prosiding Universitas Muhammadiyah Surakarta.

Johnson, E B. (2014). Contextual Teaching and Learning. Ibnu Setiawan (Penerjemah). Bandung: Kaifa.

Lestari, T.P., \& Sofyan, D. (2013). Perbandingan Kemampuan Proses Pemecahan Masalah antara Siswa yang Menggunakan Pembelajaran Creative Problem Solving (CPS) dan Konvensional. Jurnal Mosharafa, 2(3), 180-190.

Mahmudah, R dkk. (2015). Pengaruh Model Pembelajaran Creative Problem Solving terhadap Kemampuan Berfikir Kritis Matematis Siswa di Madrasah Tsanawiyah Kota Tangerang Selatan. [Online]. Seminar Nasional Matematika dan Pendidikan Matematika UNY.

Miliyawati, B. (2014). Urgensi Strategi Disposition Habits Of Mind Matematis. [Online]. Jurnal Infinity, 3(2), 174-188.
Mitchell W.E. \& Kowalik, T.F. (1999). Creative Problem Solving (3rd ed.). Bufallo, New York, NY: Genigraphics, Inc.

Mullis, I. V. S., Martin, M.O., Foy,P. \& Hooper, M. 2016. TIMSS 2015 International Result in Mathematics. Retrieved from Boston College, TIMSS \& PIRLS International Study Center.

Novitasari, D. (2015). Penerapan Pendekatan Pembelajaran Creative Problem Solving (CPS) Sebagai Upaya Meningkatkan Kemampuan Berpikir Kritis Matematis Siswa. [Online]. Jurnal Fibonachi, 1(1), 43-56.

Nurmala, N., Rohaeti, E.E., Sariningsih, R. (2019). Pengaruh Habits of Mind (Kebiasaan Berpikir) terhadap Pemecahan Masalah Matematik Siswa SMP. [Online]. Journal On Education, 1(2), 181-185.

Pepkin, K. L. (2000). Creative Problem Solving in Math.

Peraturan Menteri Pendidikan dan Kebudayaan RI No 20 Tahun 2016 Tentang Standar Isi Pendidikan.

Prameswari, G., Apriana, R., \& Wahyuni, R. (2018). Pengaruh Model Inquiry Learning terhadap Kemampuan Berpikir Kritis Matematis Siswa pada Materi Fungsi Kuadrat Kelas X SMA Negeri 3 Singkawang. [Online]. Jurnal JPMI, 3(1), 35-40.

Razak, F. (2017). Hubungan Kemampuan Awal terhadap Kemampuan Berpikir Kritis Matematika Pada Siswa Kelas VII SMP Pesantren Immim Putri 
Minasatene. [Online]. Jurnal Mosharafa, 6(1), 117-128.

Russeffendi, E.T. (2005). Dasar-Dasar Penelitian Pendidikan dan Bidang NonEksakta Lainnya. Bandung: Tarsito. Sanjaya, W. (2008). Strategi Pembelajaran Berorientasi Standar Proses Pendidikan. Kencana Prenada Media Group. Jakarta.

Setiawan, J \& Royani, M. (2013). Kemampuan Berpikir Kritis Siswa SMP dalam Pembelajaran Bangun Ruang Sisi Datar dengan Metode Inkuiri. [Online]. Jurnal Edu-Mat, 1(1), 1-9.

Soedjadi, R. (1995). Pendidikan, Penalaran, Konstruktivisme, Kreativitas sajian dalam Pembelajaran Matematika. Makalah Seminar Nasional Matematika. Surabaya: Media Pendidikan IKIP Surabaya.

Sumantri, M. (2014). Perkembangan Peserta Didik. Tangerang Selatan: Universitas Terbuka.

Sumarmo, U. (2010). Berfikir dan Disposisi Matematik: Apa, Mengapa, dan Bagaimana dikembangkan pada peserta didik. [Online]. FMIPA Universitas Pendidikan Indonesia.

Sumartono \& Yustari, E. (2014). Penerapan Model Creative Problem Solving (CPS) dalam Pembelajaran Matematika di Kelas VIII SMP I. [Online]. Jurnal Pendidikan matematika Edu-Mat, 6(2), 187-193.

Sundayana, R. (2018). Perbandingan Desain Pembelajaran ASSURE dan PPSI untuk Meningkatkan Kemampuan
Pemecahan Masalah Matematis dan Kemandirian Belajar. Mosharafa: Jurnal Pendidikan Matematika, 8(1), 143-154.

Umar, W. (2013). Pengembangan Mathematical Thinking Berorientasi pada Gaya Kognitif dan Budaya Siswa. Makalah diterbitkan pada jurnal Pend. Matematika UM. Malang: UM.

UNDP. (2017). Human Development Index (HDI). United Nation.

\section{Riwayat Hidup Penulis}

\section{Samsul Nurdiansyah, S. Pd.}

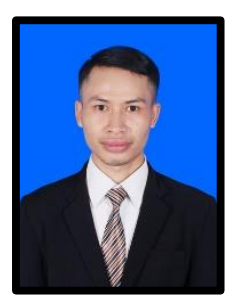

Lahir Lahir di Garut, 3 Mei 1994. Lulusan S-1 Pendidikan Matematika Fakultas IImu Terapan dan Sains IPI Garut, tahun 2020.

\section{Dr. Rostina Sundayana, M.Pd.}

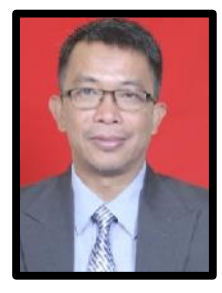

Lahir di Garut, 28 Desember 1966. Lulusan S-3 Pendidikan Matematika UPI Bandung tahun 2018. Dosen PNS dpk. IPI Garut.

\section{Teni Sritresna, M. Pd.}

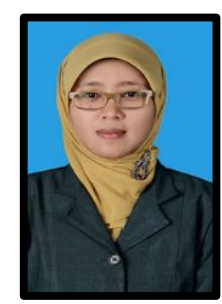

Lahir di Garut, 4 Maret 1987. Lulusan S-2 Pendidikan Matematika UPI Bandung tahun 2015. Dosen Tetap Yayasan IPI Garut. 